\title{
THE PROTESTANT WORK ETHIC AND ATTITUDES TOWARDS WORK
}

\author{
Raluca RUSU \\ rbalasoiu@yahoo.com \\ “NICOLAE BĂLCESCU” LAND FOCES ACADEMY, SIBIU, ROMANIA
}

\begin{abstract}
In this paper we will present the concept of Protestant Work Ethics as conceptualized and measured by several authors, starting with its initiator, Max Weber, in order to emphasize the importance of work ethic on attitudes towards work. We will also analyze the four dimensions of work ethic - hard work, nonleisure, independence and asceticism, identified by Blau and Ryan (1997) among military students, trying to identify how they vary according to a series of socio- demographic data of military students.
\end{abstract}

\section{KEYWORDS:}

Protestant ethics of work, hard work, nonleisure, independence, asceticism

\section{Introduction}

We are witnessing the birth of a new organizational world that values more than previously knowledge, talent, learning, motivation, ethical behavior or innovative spirit. Regardless of how this new organizational world was called: intelligent organizations (Quinn, 1992), learning organizations (Senge, 1990), adhocracies (Toffler, 1990), their efficiency, whether state-owned or private, from industry or services, whether large or small, depends largely on the extent to which they manage to recruit, retain and reward motivated employees, dedicated to the goals of their organization and occupation (Behn, 1995; Norris, 2004). In this context there is also the discussion about the work ethics, seen in the general sense as the measure in which people valorize the work (Morrow, 1993).

\section{Protestant work ethic}

The concept of work ethic has developed from the writings of Max Weber, at the beginning of the twentieth century, which was frequently credited for the contribution made to the success of the capitalist in Western countries through what became known as the Protestant Work Ethic (Van Ness, Melinsky, Buff \& Seifert, 2010).

In his book, Protestant Ethics and the Spirit of Capitalism, Weber starts from the hypothesis that the Protestant religion created the conditions for the development of capitalism. The author does not deny that there have been other social and economic factors that have led to the development of capitalism, or that other religions would have contained work-related teachings, such as Catholicism. His original argument was that Protestants were among the 
"chosen ones", having a favored status (Weber, 1993).

The essence of this concept is the belief that hard work is good instinct and leads to the desire to work even more. Also, individuals who support the Protestant ethics of work believe that hard work is necessary in order to become successful and that there are negative consequences if we do not work hard and do not live in an ascetic way (Townsend \& Leigh L. Thompson, 2013).

The most important moral-religious obligation was business success, known as vocation and success became a testament to the fact that man was chosen. Thus, the work has turned from a necessity of satisfying needs into a vocation, that is, according to Weber, work for the sake of work, for the permanent accumulation of wealth and its use in a spirit of asceticism. Two aspects are specific to the Protestant ethics of work, on the one hand the presence of a constant viewer who sees everything, namely God and, on the other hand, that work is not for a particular purpose, but simply the work for the work itself. (Weber, 2003) These two aspects have created a life-centered work and have led to the birth of capitalism. Aron (1970, 218) stated "The essence of capitalism as it was conceived by Weber is embodied in the enterprise whose goal is to obtain maximum profit and whose means are the organization of labor and production". Consequently, rationality and bureaucracy are inevitable in capitalism, creating an "iron cage" in which man is imprisoned and deprived of the pleasure of life.

Contemporary definitions stripped the concept of religious aspects and saw the Protestant work ethics as "a set of beliefs, which mainly but not exclusively concern work" (Furnham, 1990, 33). Also, some authors referred to the concept only as the "work ethic" (Blau \& Ryan, 1997; Morrow, 1993) - because studies show that work ethics is applicable to all religions. Although we can see that work ethic is on average stronger in Protestant countries (as Weber states) compared to predominantly Catholic countries (Giorgi \& Marsh, 1990; Hayward \& Kemmelmeier, 2011).

If we refer to today's work ethic, we can say that Weber's work ethic definition is nothing more than an ideal scheme, closer to an ideology than to the values in life. The significance of the concept has been enriched by considering work as a way of self-reliance and self-expression. For modern man, work is a duty, a sign of virtue and personal satisfaction (Giorgi \& Marsh, 1990).

In conclusion, the essence of this concept is the belief that sustained work is inherently good and leads to the desire to work even more. The multidimensionality of the concept includes, in addition to sustained work and discipline, temperance, diligence and desire for independence (Cohen, 2003).

\section{Measuring work ethic}

The most general tool to measure of work ethics and which was the basis for the emergence of the later instruments, was developed by Mirels and Garrett (1971) and consisted of 19 items. This scale considers both the belief that sustained work leads to success as well as the value of an ascetic life and the condemnation of leisure by relaxation (Townsend \& Thompson, 2014). It includes items like: "Any man who is able and willing to work hard has a good chance of succeeding", "People who fail to work have usually not tried hard enough", "Life would have very little meaning if we never had to suffer", and "Our society would have fewer problems if people had less leisure time" (Townsend \& Thompson, 2014). The problem of this scale is that it does not measure work ethics as a multidimensional structure as it is presented in Weber's original thesis on Protestant Work Ethic and other works that talk about work ethic.

Another interesting way to better understand the concept of work ethic and to 
operate it properly belongs to Furnham (1990). The author, based on the factual analysis of 77 items in seven scales, highlighted seven factors as belonging to work ethics, namely: belief in hard work, leisure avoidance, religious belief, morality, independence from others and asceticism. Therefore, a scale of 57 items, grouped on the seven factors resulted, which is impractical for a research approach.

Recently, two other scales have been highlighted in work ethic studies, namely: Work Ethic Scale (Blau \& Ryan, 1997) and Multidimensional Work Ethic Profile (Miller, Woehr, \& Hudspeth, 2002). The Multidimensional Work Ethic Profile (Miller et al., 2002) includes the following dimensions in the analysis of work ethics: leisure, wasted time, self-reliance, centrality of work, delay of gratification, belief in hard work and morality/ethics and Blau and Ryan (1997) use 25 items from Furnham's final list (Van Ness, Melinsky, Buff \& Seifert, 2010).

The authors also suggested a short version of 13 items, which is also of multidimensional nature, comprising the dimensions: hard work (the work itself is good introspection \& leads to success), nonleisure (the belief that spending leisure time relaxes the individual) independence (independence from others, a certain degree of autonomy indicates superiority), asceticism (a severe self-discipline and the avoidance of all the ways that create pleasure, austerity). In this study we will use this scale.

Work Ethic Scale by Blau and Ryan (1997, 442-443)

Table no. 1

\begin{tabular}{|c|c|}
\hline Hard Work & $\begin{array}{l}\text { 1. If one works hard enough, he or she is likely to } \\
\text { make a good life for him. } \\
\text { 2. If you work hard you will succeed. } \\
\text { 3. Hard work makes one a better person. }\end{array}$ \\
\hline Nonleisure & $\begin{array}{l}\text { 4. People should have more leisure time to spend in } \\
\text { relaxation }(R) \\
\text { 5. More leisure time is good for people }(R) \text {. } \\
\text { 6. Life would be more meaningful if we had leisure } \\
\text { time }(R) \text {. }\end{array}$ \\
\hline Independence & $\begin{array}{l}\text { 7. Only those who depend on themselves get ahead in } \\
\text { life. } \\
\text { 8. One should live one's life independent of others as } \\
\text { much as possible. } \\
\text { 9. To be superior a person must stand-alone. }\end{array}$ \\
\hline Asceticism & $\begin{array}{l}\text { 10. You can't take it with you, so you might as well } \\
\text { enjoy yourself. } \\
\text { 11. If you've got it, why not spend it. } \\
\text { 12. Eat, drink and be happy, because who knows what } \\
\text { tomorrow will bring?", it reflects the proper } \\
\text { orientation toward life (R). }\end{array}$ \\
\hline
\end{tabular}




\section{The perception of work in romanians}

Although there are voices who wonder if work ethics is still a relevant issue in this era of organizational change, we think it is more important than ever. Given that today's organizational world, as Nussbaum (1986) suggests, can also be considered the end of organizational loyalty, by understanding how work values help shape attitudes and behaviors, organizations have only to gain if they employ a high ethics of work and will be able to adapt more effectively.

The way in which work is viewed in a society tells a lot about the people who compose it. A very important aspect considering, as Marrow (1983) states, that work values are further passed through the process of socializing of younger generations. As it emerges from the European Values Survey and the World Values Survey, in Romania, work is seen as a central value more than half of Romanians think work is very important in their lives $(55.9 \%)$. Of the valued things, only the family occupies a more important place (93.1\%), leisure time, friends, and especially politics, are less important.

The importance of work in the Romanian society is also revealed by the answers to a series of questions about attitudes towards work, as shown in Table no. 2 .

Table no. 2

Attitudes towards work

\begin{tabular}{|c|c|c|c|c|c|}
\hline & For & 2 & 3 & 4 & Against \\
\hline $\begin{array}{c}\text { Work must always be first } \\
\text { lazy }\end{array}$ & 24 & 31 & 28 & 9 & 4 \\
\hline $\begin{array}{c}\text { People who do not work become } \\
\text { laze get money } \\
\text { It is humiliating to githout working for them }\end{array}$ & 21 & 31 & 27 & 10 & 6 \\
\hline
\end{tabular}

Source: Attitudes to Work in Romania 2008 - The Gallup Organization, Soros Foundation Romania

As you can see work is more important than free time, the answers show that you have to work to distinguish yourself as a man, that it is humiliating for someone to receive money without work and that people who do not work become lazy. In the same study, beyond the global image of attitudes towards work, their variability has been highlighted according to a range of socio-demographic characteristics. Valorization of work is quite different, so it is a bit higher for men, increases with age and with a higher position in the organizational hierarchy (Comşa, Rughiniş \&Tufiş, 2008)

\section{Study on work ethic among military students}

We will continue to analyze the work ethic according to the Work Ethic Scale by Blau and Ryan scale (1997) among military students, more precisely we will identify and hierarchize the dimensions of work ethics: hard work, nonleisure, independence, asceticism. The sample used consists of 140 military students from the "Nicolae Bălcescu" Land Forces Academy in Sibiu, girls and boys belonging to all military branches.

In order to identify the dimensions of ethical work among the sample of the 
military students, we calculated the average of the items included in each dimension of work ethic (sustained work, spending leisure time without relaxation, independence, asceticism), and then we ranked the four dimensions of work ethic (see Figure no. 1).

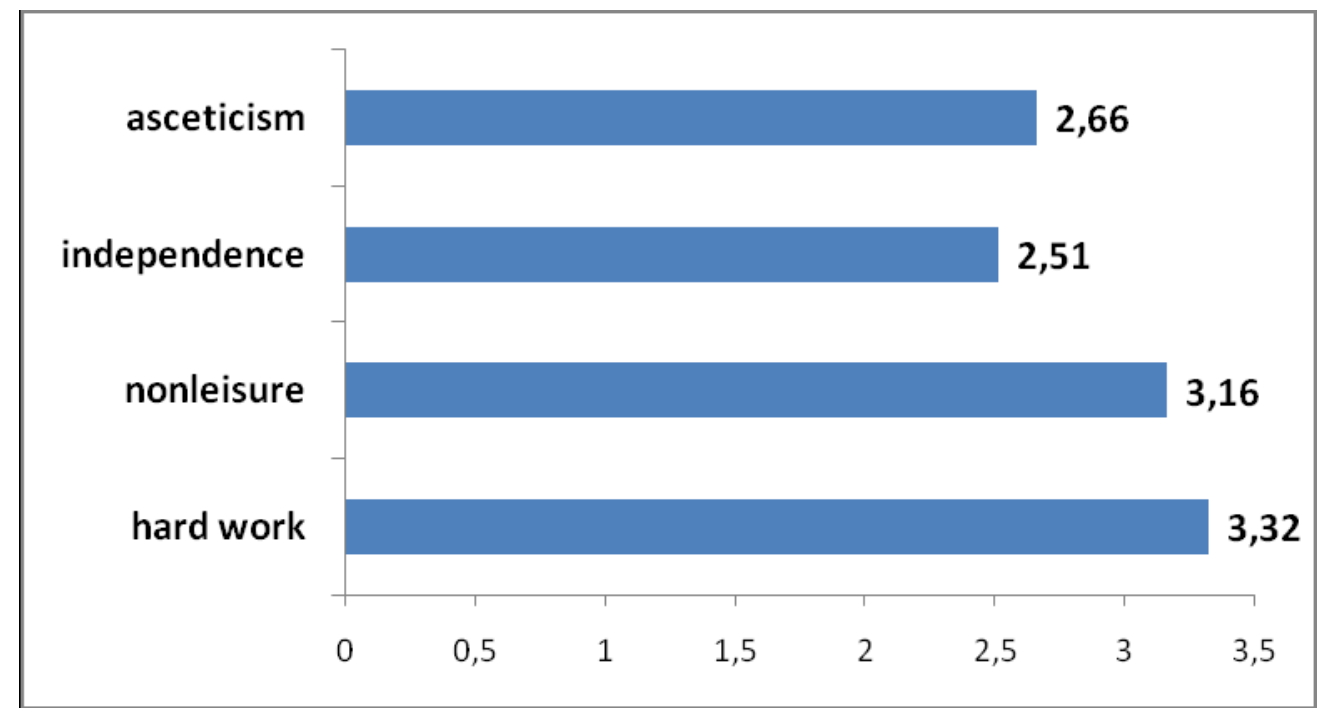

Figure no. 1 Dimensions of ethical work among military students

Although the differences between the four dimensions of work ethic are not very large, they are significant. Because the average given for hard work is slightly higher than for the other categories (3.32), we can say that military students are aware that work is the one that will bring success and the possibility of self-reliance. The analysis shows that the military students who graduated from a civilian high school $(56.6 \%)$ are more likely to value the work than those who have graduated from a military high school $-39.7 \%$. Valorization is also higher among male students compared to females and increases slightly with age (we can not talk about significant age differences among students). Also, if we look at the military branches, those who specialize in a fighting branch (infantry, mountain troops, research, paratroopers, and military police) consider work to be more important in life than those who are studying in the branches intendancy and finance-accounting. And, from the category of fighting branches, those from infantry (41 \%) have the most favorable attitude towards work.
Given the traditionalist-modern character of the Romanian society, it is no wonder that in terms of the nonleisure dimension of work ethic, we find that military students value work more than leisure time. This size varies greatly depending on the military branch, so, as with the hard work dimension, the fighter branches are more labor-oriented than other branches. For example, only $8.8 \%$ agree with the statement People should have more leisure time to spend in relaxation and the rest responded with disagreement $(59.6 \%)$ or strong disagreement $(30.9 \%)$ - the difference up to $100 \%$ represents NR/NS. Surprisingly enough, most military students also answered the question People should have more leisure time to spend in relaxation with disagreement $(59.8 \%)$ and strong disagreement $(30.9 \%)$.

The means in the other two dimensions are slightly lower, which means that students consider independence necessary for success and the inclination for an ascetic life does not belong to everyone. As for asceticism, the choices of military students, as A. Etzioni $(2002,70)$ states, falls within the scope of "voluntary simplicity" - that is, 
people choose voluntarily some austerity in their personal lives. Still, to the statement. If you've got it, why not spend it, responses were divided: $53 \%$ of students agreed with the statement, and $67 \%$ responded with disagreement.

\section{Conclusions}

In conclusion, we can state that the results of the analyzes are in line with the
Protestant work ethic, namely that we show that the students value work and realize that the responsibility to live according to moral values is important. The high level of work ethic among military students should become a sine qua non condition if it is desired to increase educational and organizational performance.

\section{REFERENCES}

Aron, R. (1970). Sociology and the Philosophy of Human Rights. In Howard Evans Kiefer \& Milton Karl Munitz (eds.), Ethics and Social Justice. Albany, State University of New York Press, 218.

Behn, R. (1995). The big questions of public management. Public Administration Review, 55(4).

Blau, G., \& Ryan, J. (1997). On Measuring Work Ethic: A Neglected Work Commitment Facet. Journal of Vocational Behavior, 51 (3), 435-448.

Cohen, A. (2003) Multiple commitments in the workplace: An integrative approach. Mahwah, NJ: Lawrence Erlbaum Associates.

Comșa, M., Rughiniş, C. \& Tufiș, C. (2008). Atitudini față de muncă în România: Opinii, realități, așteptări. București: Fundația Soros România.

Furnham, A. (1990). The protestant work ethic and vocational preference. Journal of Organizational behavior, Vol. 11(1), 33.

Giorgi, L. \& Marsh,C. (1990). The protestant work ethic as a cultural phenomenon. European Journal of Social Psichology, Vol. 20, Issue 6, 499-517.

Miller, M., Woehr, D. \& Hudspeth, N. (2002). The Meaning and Measurement of Work Ethic: Construction and Initial Validation of a Multidimensional Inventory. Journal of Vocational Behavior, 60(3), 451-489.

Mirels, H. L., \& Garrett, J. B. (1971). The Protestant Ethic as a personality variable. Journal of Consulting and Clinical Psychology, 36(1), 40-44.

Morrow, P. C. (1993). The Theory and Measurement of Work Commitment. Greenwich, CT: JAI Press Inc.

Norris, P. (2004). Still a public service ethos? Work values, experience and job satisfaction among government workers. Cambrige, MA: Harvard University.

Nussbaum, B. (1986). The end of corporate loyalty? Business Week, August 4, 42-49.

Quinn, J.B.(1992). Intelligent Enterprise. New York: The Free Press.

Senge, P.M. (1990). The Fifth Discipline: The Art and Practice of Learning Organization. New York: Currency Doubleday.

Toffler, A. (1990). Al treilea val. Bucureşti: Politica.

Townsend, S. S. M., \& Thompson, L. (2013). Implications of the Protestant work ethic for cooperative and mixed-motive teams. Organizational Psychology Review, 4(1), 4-26.

Van Ness, R. K., Melinsky, K., Buff, C., \& Seifert, Ch. F. (2010). Work Ethic: Do New Employees Mean NewWork Value?. Journal of Managerial Issues, 22 (1), 10-34.

Weber, M. (1993). Etica protestantă şi spiritul capitalismului. Bucureşti: Humanitas. 